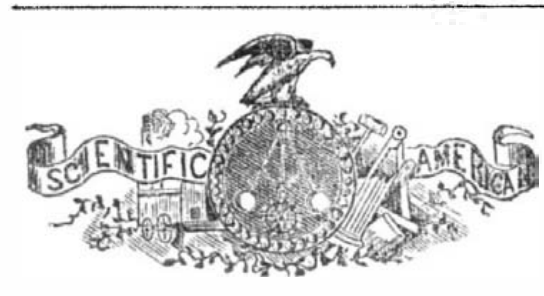

NEW YORK, JULY 10, 1847.

\section{Ventilation and Health.}

"The breath of man is in his nostrils," and according to the purity or impurity of the air we inhale, so may we expect health or sickness. The Almighty has wisely designed that labor should be one grand means of health to man, and in harmony with his great plans, motion is the principle of all creation's heaith The earth spins upon its axis, the sea rolls in mountainous waves and the atmosphere roars in the whirlwind. If the sea be not $\sim n$ tinually in motion, it will stagnate and the at mosphere without motion, would sonn be come offensive and hurtful. Inaction is one came offensive and hurtful. Inaction is one one means of purification. There are also other causes which deteriorate the atmosphere and render it injurious to those who breath it. The act of breathing throws much impurities in to the atmosphere, as the air is exposed when taken into the lungs to a surface thirty times that of the human body, or 170 000,000 of minute cells in which it is decomposed and deprived of its oxygen, and then carbonic acid gas, a deadly poison, is the produce of this wonderful labaratory. It is therefore apparent to all, that unless there is a continual supply of fresh air to the lungs, a person shut up in a confined room would soon be poisoned with his own breath. A terrible instance of this kind occurred when the Nabob of Bengal thrust one hundred and forty six
prisoners into the Black Hole of Calcutta, prisoners into the Black Hole of Calcutta,
which was scarcely large enough to contai three persons, and when out of the number stated one hundred and twenty three perished before morning amid the most dreadful sufferings. It is of the first importance to healt - the health of our families and citizens-that every attention should be paid to the ventillation of our houses, our streets, and our public buildings, and to have a knowledge of those things which injure the atmosphere, is just as essential for judging correctly of what ventillation we need, as to know that without inhal ing the at mosphere at all.life would soon droop wither and decay. It is calculated that two candles injure the air nearly as much as a human being, absorbing the oxygen which is supporter of combustion and expelling carbonic acid gas, the principal ingredient of wax and tallow. Fourteen gas lights will destroy as much as five men and from the pores of the skin three gallons of noxious fluid are thrown off from 250 persons in one hour, while from the decomposition of animal and vegetable matter, there is a continual st:eam of noxious vapor ascending and spreading. Dirty streets, pent up sewers, stagnant and impure water and confineci apartments, murder more men and women than war with all its attendant evils, for it is calculated that in England alone, more than one hundred and twenty thousand die yearly, their deaths at tributed nearly direct to thesecauses. The $d$ rect causes of all fevers, is atmospheric imp rity, and consumption and a great number of other diseases can be traced indirectly to the same source. Twenty nine died in thrs city of typhus fever last week, contracted soinewhere in an impure atmosphere and from the same cause indirectly thirty died in the same week of consumption. There can be no doubt but that the least excess of carbonic acid gas is burtful to the lungs, and when we take into consideration that a great number of males who have to labor in narrow confined rooms and in cellars lit up with air consuming gas, it is nothing but what we may expect to hear weekly, of $3: 23$ deaths, as were last week, and the mortality increasing even in a greater ratio as our population becomes larger, for although our wharves are lined with emigrants in the most miserable condition and coming from scenes of desperate fever, jet it is sad to tell that there is ar. excess of deaths by consumption over fever, showing that a gradual des-
\{ truction of life upon a most gigantic scale is means to ieed the half of Europe and send going on and by a disease traceable in most blessings to Ir $l_{\text {Ind }}$ and Scotland. For my cases to a want of free exercise in the open air. The great mother of disease, is a want of The great mother of disease, is a want of
cleanliness and proper ventillation. As far as cleanliness and proper ventillation. As far as
cleanliness is concerned, a speedy and a cheap remedy can easily be had while there is plen. ty of water, but as for proper ventillation, it will be very difficult to affect a suitable reform. Landed property is so valuable in our ity, that every inch is turned to the most money making advantage, and our public prome-
nade grounds are more stinted in all our cities nade grounds are more stinted in all our cities and villages than such places are in the older countries, probably because America is such we would specially advert, viz. the necessity of having large bedrooms. It is no uncommon thing in the construction of our build ngs, to set off a place without a single window in it, about the size of a decent box and call it a bedroom because it measures six by seven feet. Sleeping rooms should at least contain one hundred and forty superficial feet and never be less than seven and a half feet high, and have a Rumford ventillator in the window and an Arnott valve in the chimney or an open fire place. All rooms should have free access to the light of the sun, at any rate to the atmosphere, so that the impure air thrown off by the lungs or candles can pass away and pure air be admitted. Wherever as is used, there ought to be some method of llowing the carbonic to escape through tube in the eaves of the buildings, as invented by Ransom Cook.

In the city of Hamburg where so many peo ple live in cellars, it has been remarked by travellers, that blindness and all manner of physical imperfections prevail among the lower classes to a most alarming extent. While the whole world, therefore, is busy inventing and producing for the benefit of man, we must not neglect to provide for the greatest of all earthly blessings, health. Without health
there is no enjovment, and we believe that with proper ventillation and an abundance of good water, no place need be unhealthy.And with proper places for manly exercises, such as large free parks for our young men to spend an active evening hour, instead of running to ball alleys and billiard rooms, our Anglo-Saxon robustness of constitution would be as fully preserved in our cities as in our villages, and that deterioration of muscular fibre and health be preserved in our people and which now appears in sad contrast with the apparent stalwart frame

\section{Agrieuiture and Horse Power Machines.} By. o. radger.
and Horse Pov

Agriculture is a most valuable branch of our nation's industry. About four millions of our laboring and business population are engaged in it. In 1845 there were raised seven hundred and nineteen millions nine hundred and nineteen thousand bushels of grain, and in 1847 with fair crops, it is calculated that eighteen hundred millions will be raised, independent
of flax and buckwheat. This is an amount of of flax and buckwheat. This is an amount of
grain so large, that the mind can scarcely grasp grain so large, that the mind can scarcely grasp
it. The price for grain would amount to a much as would buy up some of the petty king doms of the old world. What a great and noble branch of industry then is agriculture, ye we are sorry to say that it is much undervastances who ought to do something to give consequence to .heir callings by properly edu-
cances who ought to do something to give cating their children to honor the profession of their fathers, which instead of doing, they generally engage in some mercantile business nine out of every hundred fail in realizing their expectations, and become broken down and disappointed men. We believe with Eliand disappointed men. We believe with Eli-
hu Burritt, the learned Blackstnith, that our great Western States will ere long be the Granary of the world, particularly for Eng
land, (they are so now.) With what pride land, (they are so now.) With what pride then ought every American to look uprn the great agricultural grardeur of our country
because in the hour of suffering we have enough for thurselves and enough to spare and to save from famine distant nations, and who would not be proud to belong to a class of men
whose honest industry has furnished them with blessings to Ir $(\mathrm{l}$ ind and Scotland. For my own part I, a poor humble individual, feel
proud of my country and of the little that I proud of my country and of the little that I
have done in the improvement of a branch of business that is of great importance; and this brings me to the immediate object for which I took up my pen. Agriculture is yet far bemanufacture of cotton and wool has been im-
mather manufacture of cotton and wool has been im-
proved almost to perfection, the farmer has lodded on in nearly the same old track of dam.

The threshing machines used now are nea ly the same in principle as those used twenty ears ago. A rotary cylinder with beaters or eeth running within a concave bed havin ribs or projections lying horizontal in a frame
with just space between the cylinder and conwith just space between the cylinder and con-
cave bed for the straw and grain to pass endcave bed for the straw and grain to pass end-
wise and by a succession of shocks which wise and by a succession of shocks which it receives in the passage through, the wheat is separated from the straw by the quick rotary motion of the cylinder. Threshing machines cylinder of wood covered with sheet iron and cylinder of wood covered with sheet iron and
banded strongly, having a shaft through its centre running horizontally in a frame on jourcentre running horizontally in a frame
nals boxed in as here represented.

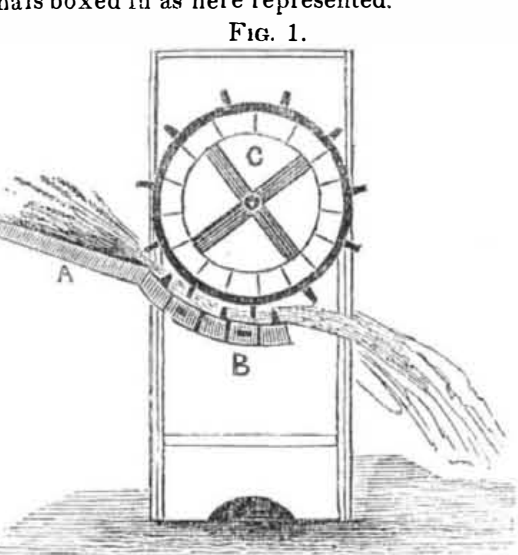

This is a sectional view of the cylinder, or sing through.

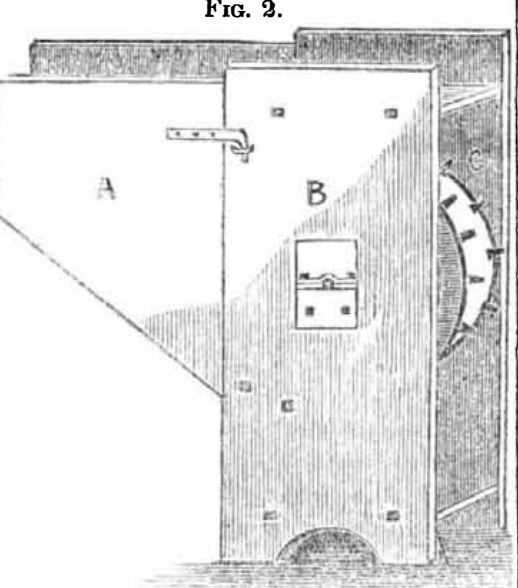

This represents a half perspective sketch f the Thresher with its plank frame and jointboits. A is the hopper, B the frame, and C the cylinder. The machines that I now make are strong and compact, and occupy less space and thresh faster than any other machines of cylinder and concave bed are armed with strong spikes which are driven in rows through strong spikes which are driven in rows through cylinder are made of half inch squareiron and tapered towards the end, and pressing through the rows on the concave bed by a quick motion must thresh cleaner and faster than any other way that has been tried. I am now manufacturing one and two horse power thresh ers and saw machines.

Fly Creek, Oswego Co., N. Y Y.

An Rixpensive Strawberry in Embryo. The Cincinnatti Horticultural Society proposes a premium of $\$ 100$ to be awarded during any strawberry season heaeafter, for the production of a new seedling strawberry suerior in size to any now cultivated in that city. A like sum is also offered for
raspberry than any now cultivated.

\section{Rallroad Iron.}

A writer in the Newark Advertiser estimate hat 180,000 tons of Railioad iron will be made in this country during the year ending 30th June, 1848. drum, $\mathrm{C}$, and concave bed with the grain pas-

Valuable for Hot Cllmates.

A gentleman in Brooklyn has discovered a

an by which the temperature inside of a dwelling miy be reduced twenty or thirty degrees below that of the air outside. He proposes to construct barracks upon this plan for the U. S. Army at Vera Cruz; and by having the soldiers live in a temperature below that which the yellow fever and other tropical diseases become contagious, he hopes to save hundreds of valuable lives. From his successful experiments, made during the warmest day this season, we are favorably impressed with its utility. The invertion can be applied to new dwellings at a very small extion. We are happy to see attention paid to such important subjects.

The inventor is Mr. Thomas G. Boone, and his method is simple and equally applicable to vessels as well as to buildings,

Increase of the Human Famlly.

According to published statistics, the popuation of the United States, since 1790, has doubled in 34 years; the British Islands, in $49 \frac{1}{2}$ years ; France, besides its loss of over $2,000,000$ by wars, \&c., in 35 years ; the German States, say 50 years ; Russia, about 35 years. Average less than 40 years.

Therefore, if the present organization of society, and the advance of arts and civilization, serve to increase the means of subsistence, of course population will increase in at least a corresponding ratio, and double in less time.

It is estimated that there are at this time $1,000,000,000$ of people on the globe, which if doubled only five times in 200 years, will make the number $32,000,000,000$. So if the whole surface of the earth, including rivers, lakes, swamps, and deserts, contains but 50 , 000,000 of square miles, or $32,000,000,000$ of acres, there will be less than one acre of land for each individual.

\title{
Oregon and Callfornia.
}

The St. Joseph's, Missouri, Gazette of the 11th inst., says-Four hundred and thirtythree wagons passed through Independence this spring, destıned for Oregon and California. 